\title{
Balconies for the Municipalities: Public Architecture and Visual Performance of Power in Early Modern Castile
}

\author{
Luis J. Gordo Peláez \\ University of Texas at Austin
}

ABSTRACT: Throughout the sixteenth century, in accordance with their status as rulers of the city, the members of the Castilian municipalities sought to establish their own buildings and balconies in the new urban centers, from where they could show themselves with the appropiate decorum on the occasion of public events and celebrations. In addition to the city halls and other civic architecture, adapted in their façades for this role as mirador or overlook, a new type of public buildings, the balconies of the city and casas de miradores, also appeared by then to accommodate the municipal governments and to visually emphasize their power.

Keywords: Early Modern Era, Castile, municipal power, civic architecture, balconies.

RESUMEN: Durante el siglo XVI, conforme a su relevante protagonismo como gobernantes de la ciudad, los concejos municipales castellanos buscaron dotarse de sus propias edificaciones y balcones en los nuevos centros urbanos desde los que mostrarse con decoro en los actos y celebraciones públicas. Junto con las propias casas consistoriales y otros equipamientos públicos, acondicionados en sus fachadas para esta función de mirador, surge también entonces una nueva tipología edilicia, la de balcones de la ciudad y casas de miradores, destinada exclusivamente a acomodar a las autoridades municipales y enfatizar visualmente su poder.

Palabras clave: Edad Moderna, Castilla, poder municipal, arquitectura pública, balcones. 
$\mathrm{I}_{\mathrm{g}}^{\mathrm{n}}$ sixteenth-century Castile, the plaza pública or chief public square gradually became a wide urban space able to host not only the market activities and the food supply, but also a number of diverse public celebrations. Any event that involved the congregation of a large audience was welcomed in the main square, whether religious festivities and liturgical events, festivals on the occasion of royal visits or other commemorations associated with the monarchs, such as births, oaths, proclamations, and funerals. In accordance with the authority entitled to them, the members of the city councils took an active part in the festivals. This demonstration and display of municipal power required an appropiate and distinguished place from where the town government officials, particularly the aldermen and the corregidor or king's representative in the city, could witness and preside over these collective events.

The use of the chief public square, plaza principal or mayor, as the center of both trade activities and celebrations definitely influenced its architectural shaping with the construction of ground porticoes and upper-floor corridors, window openings, and balconies. Given its funcionality and increasing role in the urbanism of Castilian cities, the chief public square became the best location for the city halls and other needed civic architecture whose construction had been first ordered by the Catholic Monarchs in the late fifteenth-century. ${ }^{1}$ The anonymous author of a mid-sixteenth-century treatise on architecture, labeled De arquitectura, referred to this preference of the plaza pública, emphasizing its perception as a privileged urban stage which also benefited the municipal governments by visually performing their power. He stated that if the city hall «has the exit [opened] to some main square in the town, it is tradition to see the aldermen as personas principales [important persons] and whom [inhabitants] must obey; and they [the aldermen], after being obeyed and honored, will have love for the people and will look after their well-being». ${ }^{2}$

When the municipal councils opted for the chief public square as the designated location of the city hall, often they relied on an architecture of loggias, multiple windows and balconies for the composition of the façades. For

1. Following the conquest of the Muslim Kingdom of Granada and the Canary Islands, Isabella and Ferdinand presented these territories with the Fuero Nuevo, a collection of laws and privileges conceded to the cities and towns newly incorporated into the Crown of Castile. Among other instructions, the kings ordered the municipal governments to build «a city hall, and a jail, and a specific house for the public notaries to constantly be [in there], and a hall for the hearing of the judges», and all this architecture had to be located «in the plaza or in a convenient place» (ANTONio MALPICA Cuello: «Algunos aspectos del concejo de Alhama: el gobierno municipal según el Fuero Nuevo», Cuadernos de Estudios Medievales, VIVII, 1978-1979, p. 124; J. Moreno CASADO: Fuero de Baza. Estudio y transcripción, Universidad, Granada, 1968, p. 66).

2. Anónimo de Arquitectura. Tratado del siglo XVI, edición de Cristina Gutiérrez-Cortines Corral, Dirección General de Bellas Artes y Archivos, Madrid, 1995, pp. 289-290. This manuscript, preserved in the Spanish National Library (Ms. 9681), dates back to mid-sixteenth century. On urban planning and public architecture, the author follows some of the concerns and ideas exposed a century earlier by Italian Humanist Leon Battista Alberti in his De Re Aedificatoria. See Fernando Marías Franco and Agustín Bustamante García: «Un tratado inédito de arquitectura de hacia 1550», Boletín del Museo e Instituto Camón Aznar, XIII, 1983, pp. 41-57. 
instance, in the third decade of the sixteenth-century, the council of Plasencia, a city located near the border with Portugal, was in the process of erecting a new city hall in the Plaza Mayor. By then, the aldermen were debating about what architecture was more convenient for the completion of the delantera or façade of the future building. After seeking the advice of several master architects and listening to the opinion of the population, the city council concluded that «many inhabitants of this city, almost the majoriy of them, want the said house to be built with its porticoes and [upper] corridors for many reasons that they give, [and] so after seeing the said plan [we] order and have ordered to have them where the Justice [judge or corregidor] and Aldermen [can] be in the time of joy and bull's licenses, and because the inhabitants of this city, and mostly the merchants, make the most of the porticoes». ${ }^{3}$

This use of a continuous balcony with balusters or iron rails on the top floors of the city halls offered a considerable space for the aldermen to witness the public celebrations occurring in the plazas. In fact, following the reform of the city hall, in 1575 the town government of Tudela agreed to replace the existing windows on the façade's top floor with projecting balconies. This new design, as stated by the aldermen, was necessary in order to provide more space for the «many personas nobles y de calidad [elite] that come to witness them [the public celebrations]» in the Plaza de Santa María, chief public square and seat of the city council. ${ }^{4}$

This type of façade, with a more diaphanous architecture that projected the building into the urban space, was extensively used in the Castilian city halls during the second half of the sixteenth-century. It was one of the most simple and yet most useful models of façade in public architecture. Municipalities of the Iberian Peninsula as far apart geographically as Laredo, Trujillo, San Clemente, Valladolid, Jaén, or Ciudad Rodrigo used an architectural fabric that historian Vicente Lampérez clearly defined as «the frank expression of local needs: the portico for the citizens, where, under cover, they can meet, read the edicts and look forward to the decisions; and the gallery, as a balcón concejil [balcony for the city council], from where the town government appears to the people, either in their usual duties, or using it as an overlook to witness, [together] as a [municipal] corportation, the public festivals». ${ }^{5}$

3. Archivo Municipal de Plasencia, Actas de Acuerdos del Ayuntamiento, 1522-1526, f. 141r, in Jesús Manuel López Martín: La arquitectura en el Renacimiento placentino: simbología de las fachadas, Institución Cultural «El Brocense», Cáceres, 1986, pp. 121-122.

4. Julio Segura: «Casa consistorial de Tudela», in Francisco Miranda et Al.: Casas Consistoriales de Navarra, Gobierno de Navarra, Pamplona, 1988, pp. 259-260.

5. VICENTE LAMPÉREZ y Romea: La arquitectura civil española desde el siglo I hasta el XVIII, Saturnino Calleja, Madrid, 1922, vol. II, p. 92. The Plaza del Mercado Chico, inside the town walls, was, along with the Plaza del Mercado Grande, one of the two urban spaces used for public celebrations in Ávila. A recently remodeled city hall, provided with a balcony, served the municipal council to participate in festivals, such as the one occurred in September 1594, when the remains of San Segundo, saint patron of Ávila were transferred from its original church to the cathedral. This relocation, described by Antonio de Cianca, was celebrated with several festivities, some of them organized in front of the municipal balconies in Plaza del Mercado Chico. In that occasion, in addition to the windows and openings of the city hall, a tablado 
According to these ideas, the contract for building the new city hall of Laredo, approved by its municipality in 1557 and executed by architect Juan de Cerecedo, stipulated that in the new architectural fabric there would be a twostory building with ground porticoes and upper-floor galleries, «the arches of the said work and house must go all around». This design clearly emphasized the preference of the aldermen for an open façace that also conceived the city hall as a municipal balcony [Fig. 1]. ${ }^{6}$

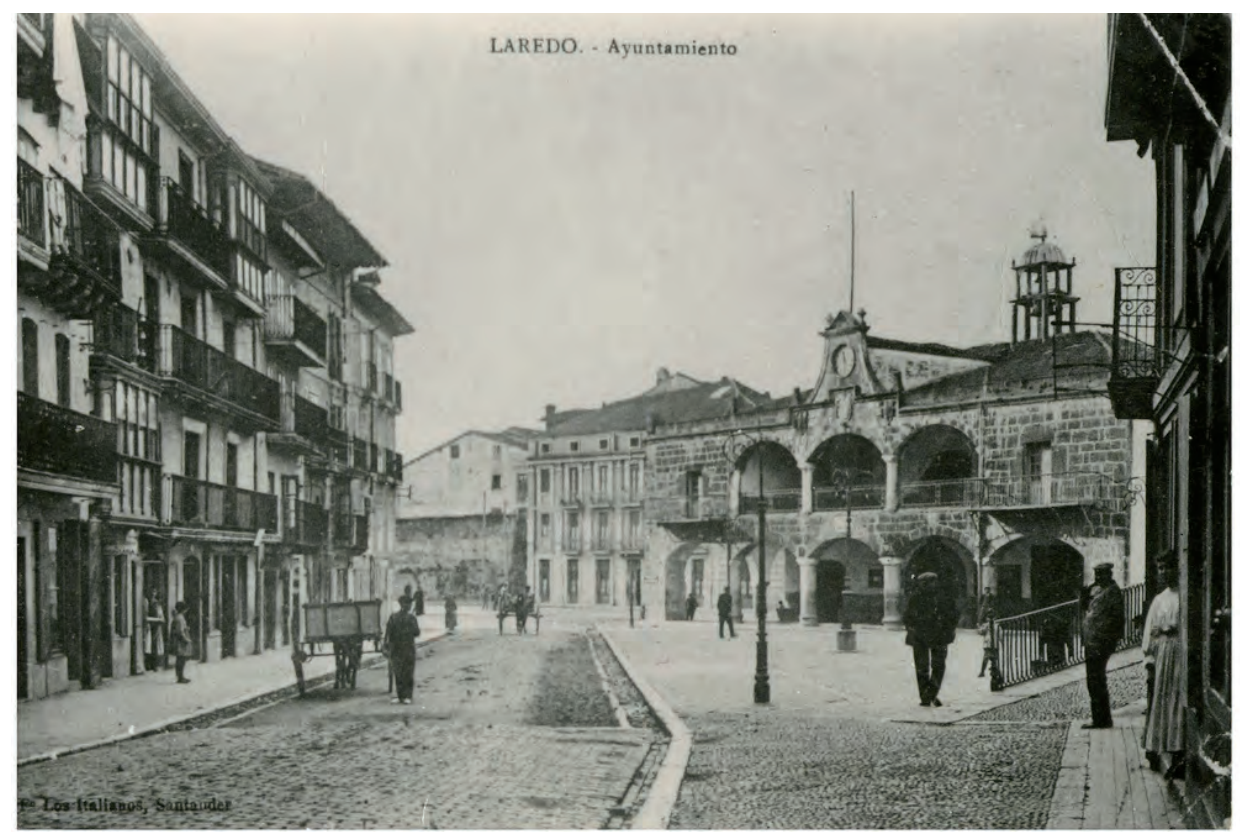

Fig. 1. City hall, Laredo, Circa early 20th century, Source: Asociación de Amigos del Patrimonio de Laredo, http://www.flickr.com/photos/22126241@N02/2133797236/in/set72157603885999101/ [access: June 1, 2012].

\footnotetext{
or wooden stage was used by the political and ecclesiastical authorities of Ávila to witness, among other events, the Miguel Sánchez's «famous comedy of La Isla Bárbara» (Antonio DE Cianca: Historia de la vida, invencion, milagros, y translacion de S. Segundo, primero Obispo de Auila: y recopilación de los Obispos sucessores suyos hasta D. Geronimo Manrique de Lara, Inquisidor general de España, Luis Sánchez, Madrid, 1595, ff. 67r, 68r).

6. By mid-sixteenth century, the council of Laredo was in serious need of a more decent and appropiate construction, able to accentuate the prestige of a city that was still an important seaport in the Cantabrian Coast and one of the capitals of the corregimiento or district of Cuatro Villas de la Costa de la Mar. In fact, the camino real or royal road used for merchants trading between Castile and Northern Europe ended in this town; and Laredo was also chosen in several occasions by the early sixteenth-century Spanish monarchs either to sail or return from their trips to Flanders (Antonio Bravo y Tudela, Recuerdos de la villa de Laredo, Asociación del Arte de Imprimir, Madrid, 1873, p. 247; M. Bustamante Callejo: «Notas para la historia de la Villa de Laredo», Altamira, 1, 2 y 3, 1962, pp. 180 y 182; Begoña Alonso Ruiz: Arquitectura Tardogótica en Castilla: Los Rasines, Universidad de Cantabria, Santander, 2003, pp. 316-318).
} 


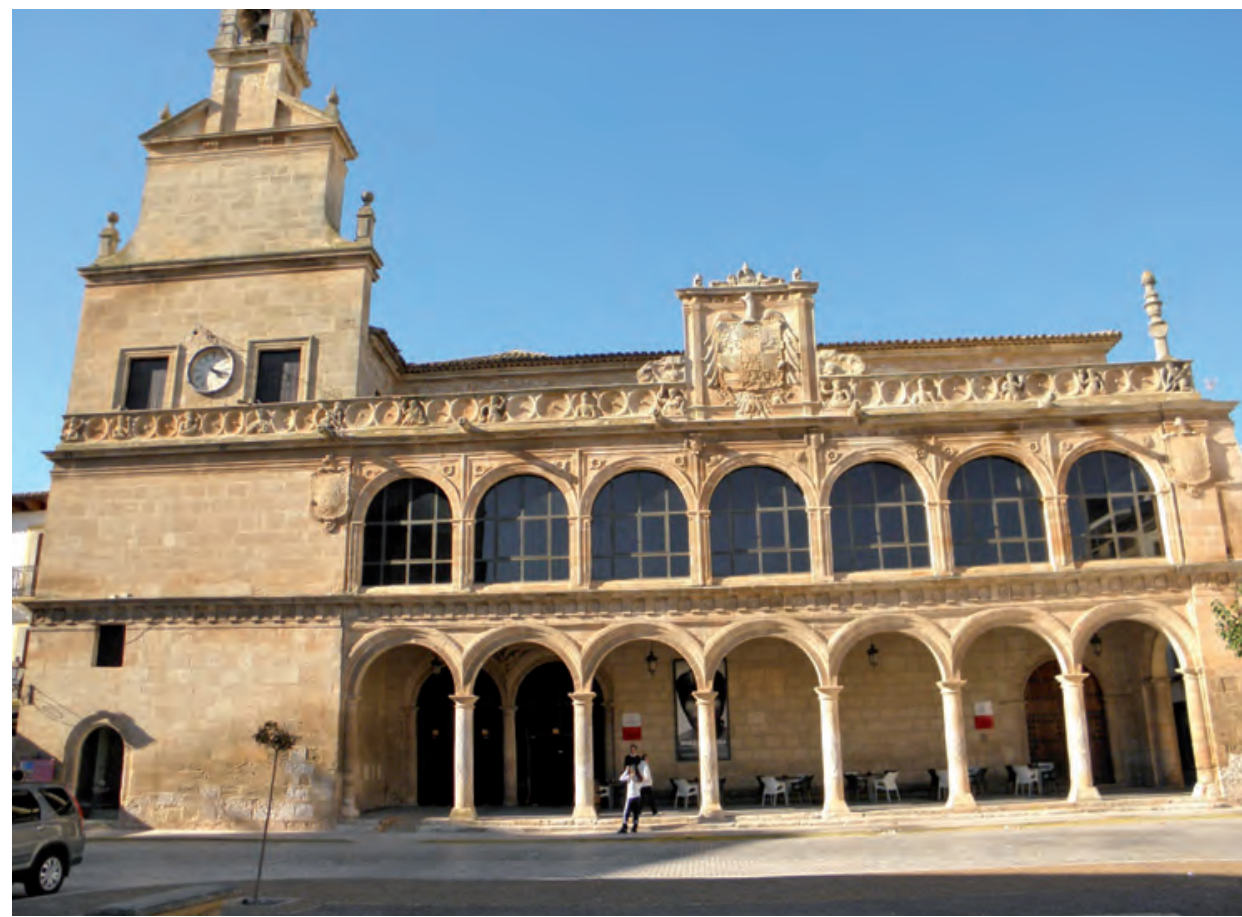

Fig. 2. Plaza Mayor and City hall, San Clemente, Source: http://tiltide.blogspot.com/2011/11/ museo-de-obra-obra-grafica-fundacion.html [access: June 1, 2012]

The same type of architecture seemed to be in the mind of the diligent corregidor Jerónimo Castillo de Bovadilla when he promoted the construction of a «very good city hall» in Guadalajara, a city located to the northeast of Madrid. This building, which was completed in 1585, anticipated what the mentioned royal magistrate would recommend a few years later regarding the construction of city halls. ${ }^{7}$ Located in the chief public square, the new building for the aldermen also housed in its interior «the jail with the courtrooms, and also the corregidores' dwelling». ${ }^{8}$ Also, for the aldermen and corregidor to publicly exhibit their authority as representatives of the city and the king, the front of the new construction was designed as a privileged balcony over

7. In his treatise on the office of corregidores, published in 1597, Castillo de Bovadilla affirmed that «it is not right for the corregidor to reside elsewhere but in the palacio público [public palace or city hall] because he must neither take nor occupy the subjects' houses or, according to Plato and Aristotle, to live separately from the jail, the court rooms, and the plaza» (Jerónimo CAstillo de Bovadilla: Politica para Corregidores y señores de vassallos, en tiempo de paz y de guerra. Y para juezes eclesiásticos y seglares $y$ de Sacas, Aduanas, $y$ de Residencias, $y$ sus Oficiales: y para Regidores, y Abogados, $y$ del valor de los Corregimientos, y Goviernos Realengos, y de las Órdenes, Iuan Bautista Verdussen, Amberes, 1704 [first edition: Madrid, 1597], vol. II, pp. 75-76).

8. Francisco De Torres: Historia de la muy noble ciudad de Guadalaxara, 1647, Biblioteca Nacional, Madrid, Ms. 1689, ff. 40v-41r; Alonso NúÑEz DE CASTro: Historia eclesiástica y seglar de la mvy noble y mvy leal civdad de Guadalaxara, Pablo de Val, Madrid, 1653, pp. 4-5. 
the Plaza Mayor of Guadalajara. A few decades later, in the mid-seventeenth century, local chonicler Alonso Núñez de Castro praised the virtues of this new architectural fabric which, «in order to see the public festivals, it has a good corridor at the front, carved in marble». ${ }^{9}$

The functionality of this open façade and the increasing role of the chief public square as center of the civic and religious festivals explains why some sixteenth-century municipalities agreed to altere or expand their existing city halls in order to better meet these needs of visual performance of power. In Sevilla, the municipality initiated the arrangements to build a city hall for their meetings following the visit of Emperor Charles V in 1526. Until then, the town government had shared a house with the members of the cathedral chapter. By the early sixteenth-century, this building was seen as inappropiate and small for the distinction of the city and its representatives. For the new building, the aldermen decided on a different location near the city's Franciscan convent, in an open space that would gradually developed as a more regular plaza and the main urban center of Sevilla. ${ }^{10}$

Facing this Plaza de San Francisco, master architect Diego de Riaño designed a two-story building that included all the needed quarters and rooms for the municipal government. As for the façade, Riaño chose a solid construction in good hewn stone, which consisted of a central doorway and several window openings. This splendid architecture, along with the emblematic ornamentation carved in the interior and exterior of the building, reflected the authority of the municipal government, in accordance with the illustrious history of the city. ${ }^{11}$ However, a few decades later, this first building needed to be expanded. Sevilla had become one of the wealthiest and most populated cities in the Spanish Empire, and the Plaza de San Francisco was a bustling urban center, where,

9. NúÑEz de CAStro, Historia eclesiástica, pp. 4-5. In the late nineteenth-century, before being demolished a few years later, historian José María Quadrado still pointed out the open façade of the city hall, with its «portico and gallery of semicircular arches» (José MARía QuAdRAdo: España. Sus monumentos y artes. Su naturaleza e historia. Castilla la Nueva. Guadalajara y Cuenca, Daniel Cortezo, Barcelona, 1886, vol. II, p. 4). Although perhaps excessive for the population of sixteenth-century San Clemente, the city hall of this Manchego town, with its open and large façade of «fourteen arches, seven in the lower-floor and seven in the upper-floor», also offered the municipal authorities a grandiloquent and distinguished space to affirm and visualize the prestige of the city and its rulers. (See Eusebio Julián ZarCo-BaCAS y Cuevas (ed.): Relaciones de pueblos del Obispado de Cuenca, Diputación Provincial, Cuenca, 1983, pp. 474-475. See also Diego Torrente Pérez: Documentos para la historia de San Clemente (Cuenca), [Ayuntamiento de San Clemente], Madrid, 1975, vol. II, pp. 3-5).

10. In the seventeenth century, Rodrigo Caro described this former location of the city council in the following terms: «Together with the Convento of San Francisco is the city Council, which first was in the past in the Plaza del Arzobispo, in some houses that currently serve as tavern [...] In this same old city hall also met the Holy Church Chapter, occupying the city the upper-floor, and the chapter the lower part of this narrow and small building» (Rodrigo CARO: Antigüedades y principado de la ilvstrissima civdad de Sevilla, y chorographia de sv convento ivridico o antigva chancilleria, Andrés Grande, Sevilla, 1634, ff. 61v-62r).

11. See Alfredo J. Morales Martínez: La obra renacentista del Ayuntamiento de Sevilla, Ayuntamiento, Sevilla, 1981; Alfredo J. Morales Martínez: El ayuntamiento de Sevilla, Arquitectura y simbología, Ayuntamiento, Sevilla, 1981. 
in addition to the city hall, also stood the seat of the Real Audiencia, one of the high appellate courts in Early Modern Spain and an iconic symbol of royal justice in the city. French traveller A. Jouvin described this square as «one of the most important; it is surrounded by several houses, which are the dwelling of wealthy goldsmiths, where the Audiencia is, palace where the lawsuits are defended; the City Hall is not far away from there, which is one of the beautiful buildings in this city». ${ }^{12}$

By mid-sixteenth-century, architects Juan Sánchez and Hernán Ruiz the Younger had consecutively directed the works in the city hall, adding new architectural pieces to the original building designed by Riaño. One of the most significant additions to the city hall -which «completed its perfection» in the words of eighteenth-century historian Diego Ortiz de Zúñiga- was the building of an adjacent «overlook» or «mirador in the upper and lower corridor, on which were added the royal arms, those of the city, and those of the Asistente [corregidor] Mr. Francisco Chacón». ${ }^{13}$

These additional galleries, erected by the mentioned architect Hernán Ruiz the Younger and completed by 1564, were conceived in accordance with the most common model of façade in mid-sixteenth-century Castilian city halls. The seven arches that shaped these «lower and upper arcades» notably enlarged the front of the city hall in the Plaza de San Francisco. ${ }^{14}$ They helped to emphasize the physical presence of the municipal power in such a privileged public space and to offer a new balcony for the aldermen and elite of Sevilla.

Although these porticoes and corridors were demolished in the nineteenth century, they were reproduced in multiple Early Modern and Modern images that represented the Plaza de San Francisco, some of them during the celebration of public festivals. Perhaps the most eloquent image is the oil on canvas entitled "Carros del Víctor y del Parnaso», painted by Domingo Martínez in 1748 and currently preserved in the Fine Arts Museum of Sevilla [Fig. 3]. The painting represents the delivery to the city council of the royal portraits of King Ferdinand VI and Queen Bárbara de Braganza on the occassion of the celebrations organized in Sevilla to commemorate their accession to the Spanish throne. The scene takes place in a crowded Plaza de San Francisco, right at the entrance of the sixteenth-century city hall. The façade of this latter building, adorned with sumptuous tapestries and fabrics, still preserved the same architecture completed almost two hundred years earlier. Galleries and

12. A. Jouvin: El viaje de España y Portugal, in José García Mercadal: Viajes de extranjeros por España y Portugal, Aguilar, Madrid, 1959, vol. II, p. 816.

13. Diego Ortiz de Zúñiga, Anales eclesiásticos y seculares de la Muy Noble y Muy Leal Ciudad de Sevilla, Imprenta Real, Madrid, 1796 [first edition: 1677], vol. IV, pp. 21-25.

14. CARo, Antigüedades y principado ..., ff. 61v-62r. Franciscan Arana de Varflora described it in 1766 as «a beautiful and wide gallery, created with talented idea» (Fermín ARANA DE VARflora, Compendio histórico descriptivo de la muy noble y muy leal ciudad de Sevilla, metrópoli ínclita de Andalucía, Manuel Nicolás Vázquez, Sevilla, 1766, p. 47). 


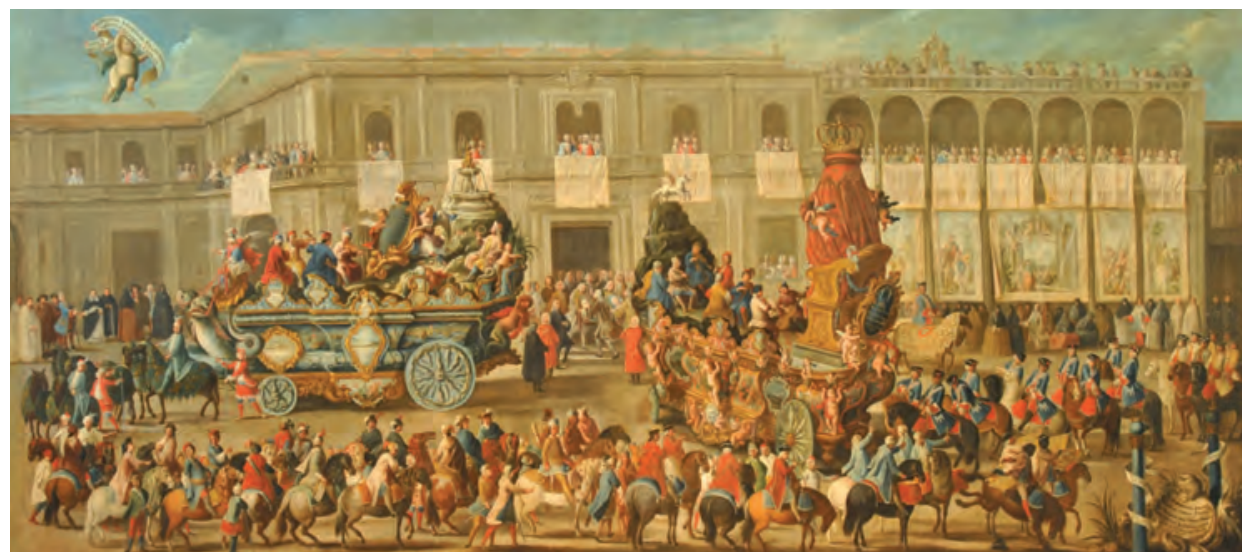

Fig. 3. Carro del Víctor y del Parnaso [view of the city hall in Plaza de San Francisco, Sevilla], Domingo Martínez, 1748, Sevilla, Museo de Bellas Artes, Source: http:// www.juntadeandalucia.es/cultura/museos/MBASE/index.jsp?redirect=S2_3_1_1. jsp\&idpieza $=18 \&$ pagina $=4$ [access: June 1, 2012]

windows, in accordance with their original purposes, are occupied by the authorities of Sevilla and its most distinguished inhabitants, participating in such a spectacular event. ${ }^{15}$

In some Castilian cities, the locations of their city halls did not always correspond to the civic space that would become their urban center and the scene of public festivals throughout the sixteenth-century and beyond. In Burgos, for instance, the Medieval Gate of Santa María was the seat of the city council during the sixteenth-century. ${ }^{16}$ Although the building was then magnificently remodeled in its architecture and adorned with an emblematic façade, it was not located along the perimeter of the nearby squares of Mercado Mayor and Mercado Menor. These adjacent squares, located across the bridge of San Pablo and inside the city walls, were the market centers of Early Modern Burgos and its most prominent public spaces. ${ }^{17}$

15. The city hall with its additional galleries and porticoes can also be clearly seen in a 1738-print attributed to Pedro Tortolero, which represents the procession of Corpus Christi in Sevilla («Vista y Perspectiva de las Casas de Cavildo de Sevilla y celebre procesión del Corpus 1738», [S.1.. s. n., 1738], Biblioteca Nacional, Madrid, INVENT/14762).

16. Alberto C. IbÁÑez Pérez: Arquitectura civil del siglo XVI en Burgos, Caja de Ahorros Municipal, Burgos, 1977, pp. 243-248.

17. During the Early Modern Era, the city hall of Logroño was situated in the Calle de la Herbentia, a «narrow and long street», as was described in 1577, that made it very difficult for some celebrations to take place in such an inconvenient location. Given the need for a larger space, in the last two decades of the sixteenth century the city council started to celebrate the bullfights and other regocijos or rejoicings in the Coso de San Francisco. A few years later, in order to increase the embellishment of Logroño, the municipal government ordered that space to be converted into a more decent square allowing the building of private houses in its perimeter, upon the condition that their façades should all follow the design given by the city (Archivo Municipal de Logroño, Libro de Actas Municipales, 1576-1578, f. 152r. and 1594-1597, f. 143r., in María Teresa Álvarez Clavijo: Logroño en el siglo XVI: Arquitectura y Urbanismo, Instituto de Estudios Riojanos, Ayuntamiento, Logroño, 2003, Apéndice Documental, pp. 657, 1202). 
When this separation happened, the municipal governments usually rented or acquired existing houses in those main squares where they did not have any building before. The architecture of these houses was subsequently reformed or adapted, sometimes modestly, to offer its illustrious occupants a balcony or space to witness the events in the plaza. However, the development of public infrastructures and civic architecture during the sixteenth century also prompted some Castilian municipalities to promote the construction of a new type of building: the balcón de la ciudad or casas de miradores. These open and terrace-like houses, or «overlooks», were exclusively designed for the town government to see and be seen on the occasion of festivals and celebrations.

This visual performance of power and prestige through the balcony or mirador was not exclusive to municipal councils in Early Modern Castile. The ecclesiastical authorities also made use of this architecture with similar purposes. For instance, in mid-sixteenth century Plasencia, the cathedral chapter owned some houses in the main public square of the city. According to the description of the dean at that time, «the windows of the first floor in these houses that are for us, the said lords Dean and Chapter» served to witness from them «all the days of bulls and usual festivities that were held in the said public square of the city of Plasencia». ${ }^{18}$

More significant and complex was the intervention of the cathedral chapter of León in the Plaza de Regla, the square to become the sixteenth-century urban center for civic and religious ceremonies. In the sixteenth century, the aldermen of León used for their regular meetings a different open space in the city, the Plaza de San Marcelo, where they occupied an old building in need of continuous repairs. ${ }^{19}$ For decades, the city council had been persisting in its attempt to attract the main public celebrations to this Plaza de San Marcelo and to convert this space into the civic center of León. In order to encourage this relocation, the aldermen even ordered some trade activities to be moved from the Plaza de Regla to San Marcelo and also promoted the construction of new public buildings related to the food supply in different squares of León. No doubt, they intended to neutralize the prominence of the Plaza de Regla as traditional market place and urban center.

Despite the desperation of the aldermen, the square of the cathedral maintained its preeminence as the most significant public space in the city. Conceding this situation, the members of the municipal government agreed

18. Archivo de la Catedral, leg. 62, n. 193, ff. 3r-3v, July 30, 1557, in Jesús Manuel López MartíN: La arquitectura en el Renacimiento placentino: simbología de las fachadas, Institución Cultural «El Brocense», Cáceres, 1986, p. 125.

19. Given the bad conditions of the old city hall in the sixteenth century, the aldermen even requested permission to the Royal Council to temporarily move to the Medieval Royal Palaces of León (See MANUEL Gómez Moreno: Catálogo Monumental de España. Provincia de León (1906-1908), Ministerio de Instrucción Pública y Bellas Artes, Madrid, 1925, pp. 303-304; A. Nieto Fernández: Catálogo de los documentos del Archivo Municipal de León, Imprenta Moderna, León, 1927, p. 93, document No. 321; José Javier Rivera Blanco: Arquitectura de la segunda mitad del siglo XVI en León, Institución «Fray Bernardino de Sahagún» de la Diputación Provincial, León, 1982, pp. 215-225). 
in 1565 to purchase a house «for adornment and embellishment of the city, and because the said plaza [de Regla] is one of the most important in the city $[\ldots]$ where festivals occur and converge most of the people». ${ }^{20}$ The aldermen's purpose was to replace that existing house, inappropiate and indecent for the embellishment of the square and the distinction of the town government, with a new and well-planned building, constituted of galleries in its upper floor that would serve them as miradores. The works on the new «balcony of the city» finally started in 1567 . However, its decentralized location in the Plaza de Regla, occupying one angle of its perimeter, was far from the prominent position usually sought in the location of these buidings and did not benefit the visual performance of power intended by the town government of León.

In accordance with their interest in creating a more distinguished and regularized space in front of the city's cathedral, the religious authorities also promoted several reforms in the Plaza de Regla throughout the sixteenth century. The so-called Casas de las Boticas, a house located in front of the cathedral's western façade, was remodeled and provided with galleries in its front; and also a new building, the Paredón de Regla [literally «Wall of Regla»], was erected in the north side of this plaza [Fig. 4]. In addition to improving the urban form of the square, this latter «wall» or house, designed by architect Juan del Ribero Rada in 1579, became a new and splendid balcony for the ecclesiastical power in the city. Moreover, this building was facing the mentioned city's balcony, located in the opposite side of the Plaza de Regla. ${ }^{21}$

Contrary to what happened in León, the sixteenth-century municipal balcony of Granada, the Casa de los Miradores, was erected in a more central location in the perimeter of the Plaza de Bibarrambla, «the major [one] and the [one] for festivals». Local historian and lawyer Francisco Bermúdez de Pedraza further wrote that this splendid square, «longer than wide, in the middle has a beautiful mirador [from] where the Regimiento [town government] observes the festivals».22 An anonymous print of 1760 , showing the festivities and parades organized in this square for the proclamation of King Charles III, clearly illustrates the preeminence given to the balcony of the municipal power [Fig. 5]. ${ }^{23}$

20. Archivo Histórico Municipal de León, Libros de Acuerdos, 5, caja 36, ff. 464-474, August 27 and 32, 1565, in Campos Sánchez-Bordona and Pereiras Fernández, Iglesia y ciudad, p. 327.

21. María Dolores Campos Sánchez-Bordona, «Proyectos urbanísticos de Juan de Badajoz y Juan del Ribero Rada para la ciudad de León», Anuario del Departamento de Historia y Teoría del Arte, IV, 1992, pp. 145-150; María Dolores Campos Sánchez-Bordona and María Luisa Pereiras Fernández, Iglesia y ciudad, su papel en la configuración urbana de León: las plazas de San Isidoro y Regla, Universidad, León, 2005, pp. 330-346.

22. Francisco Bermúdez de Pedraza, Antigvedad y excelencias de Granada, Luis Sánchez, Madrid, 1608., ff. 11r-11v.

23. Antonio Bonet Correa, «La arquitectura efímera del Barroco en España», Norba-Arte, 13, 1993, p. 54 . 


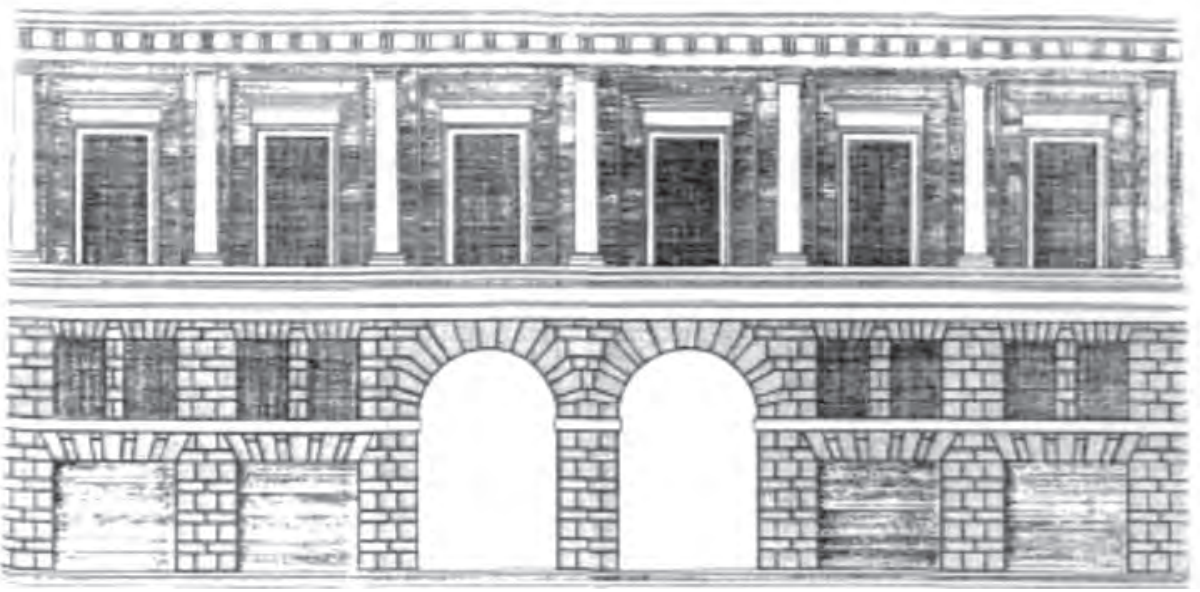

Fig. 4. Design for the Paredón in Plaza de Regla, León, Juan del Ribero Rada, Archivo Catedral de León, doc. 5. 787. Published in: María Dolores Campos SÁnchez-Bordona, «Proyectos urbanísticos de Juan de Badajoz y Juan del Ribero Rada para la ciudad de León», Anuario del Departamento de Historia y Teoría del Arte, IV, 1992, p. 149

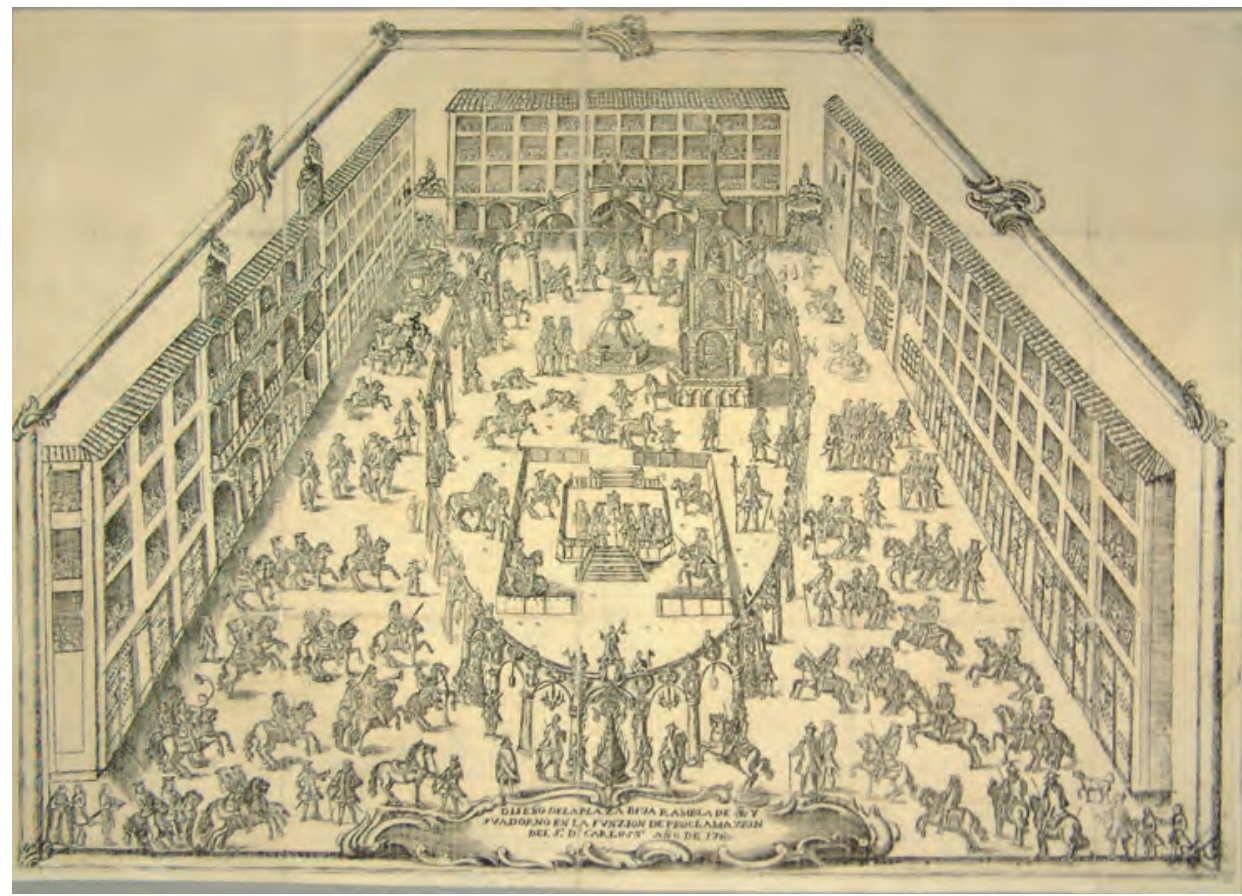

Fig. 5. Proclamación de Carlos III en la Plaza de Bibarrambla, Granada [with façade of Casa de Miradores], Anonymous, 1760. Published in: Antonio Bonet Correa, «La arquitectura efímera del Barroco en España», Norba-Arte, 13, 1993, p. 54 


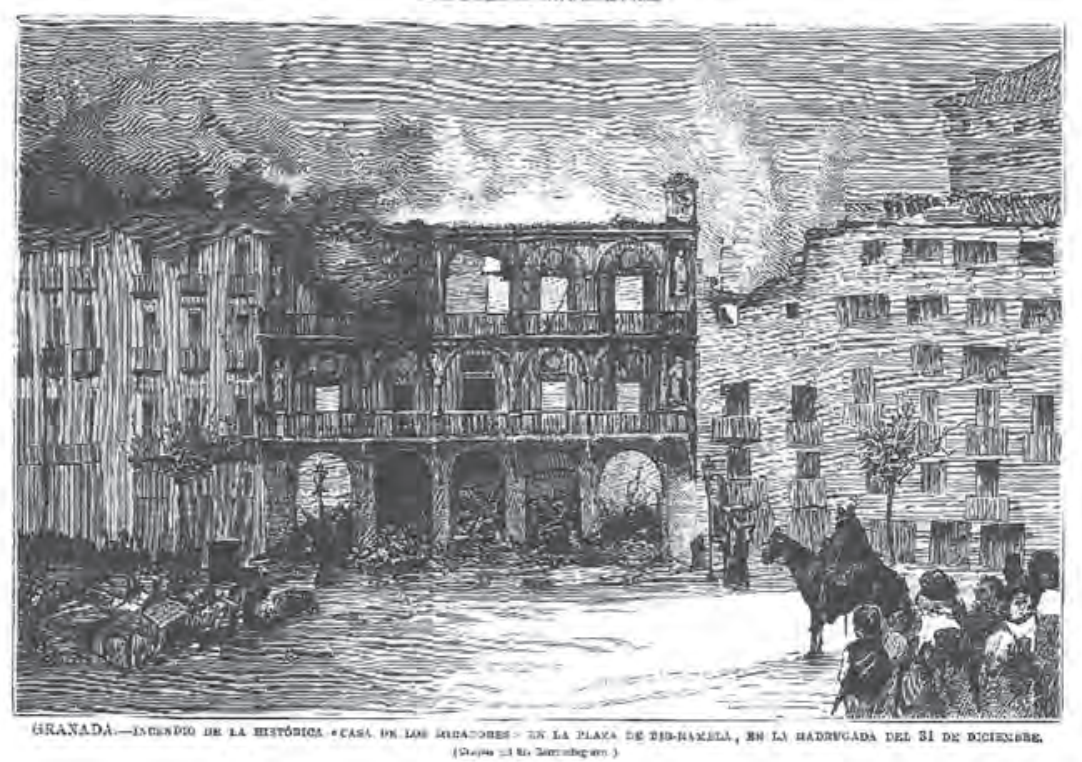

Fig. 6. Fire in the Casa de Miradores, Granada, Barrencheguren (drawing), 1879. Published in: La Ilustración Española y America, No. II, January 15, 1880, p. 28

After the reconquest of Granada, the Catholic Monarchs granted the city council permission to establish their seat in the former Madraza or Muslim School. ${ }^{24}$ Facing a narrow street and the recently completed Royal Chapel, the location of this building made it impossible to provide it with an open plaza for the festivals. Consequently, these events were transfered to the nearby Plaza de Bibarrambla, a large and open space that, after undergoing an extensive reform, became the customary and most appropiate urban stage in Granada. Following the increasing importance of this square and lacking any other municipal building in its perimeter, the city council agreed to build a new balcony inside the plaza. The resulting building reflected the design traditionally used in this type of public architecture.

These functional houses, usually consisting of one or two rectangle-shaped crujias [spaces between two supporting walls] in plan, were opened to the square with a façade of lower porticoes and upper galleries. These external corridors, frequently supported by arches, ensured the optimal view of the aldermen over the square and its celebrations. Also, it allowed the audience attending the events to clearly visualize the town government, in an elevated position and with the symbols of its authority and prestige. The Casa de los Miradores was designed by architect Diego de Siloé according to this criteria in 1560 and completed by 1583, under the direction of his disciple Juan de

24. «And we give the city hall that used to be called Madraza and the annexes to it» (Ordenanzas de Granada de 1552, Ayuntamiento, Granada, 2000 [facsimile edition], f. 4r). 
Maeda. It consisted of a three-story façade completely opened to the plaza with arcades topping pilasters and half columns of different orders. Crowning this front, a carved balustrade and three small niches with the royal and city arms were added, as was usual for the ornamentation of Castilian public buildings [Fig. 6]..$^{25}$

In order to visually perform their power in the main square, the municipal governments also used other public buildings whose original functions were different from that of balcony or mirador and so was their customary architecture. The façades of these constructions were modified given their location in squares that were used for both trade and festivals. For instance, since the beginning of the sixteenth-century, the municipality of Baeza was housed in the Palace of Cabrera, a late Medieval construction located in the Plaza de Santa María, near the city's cathedral. ${ }^{26}$ Thus, in such a singular public space converged both the ecclesiastical and political authorities of Baeza. However, part of the prominence of this urban space was to be lost throughout the sixteenth and, above all, seventeenth centuries, following the development of a new square located in the suburbs of the Medieval city. This square, the Plaza del Mercado, was originally an open space used as a market center given its favorable location at the entrance of the city. Other many Castilian cities underwent a similar process in the shaping of their urban form. The original development of these market squares, located in the arrabales or suburbs, often originated in the sixteenth-century; however, its culmination would be complete, in many cases, in the seventeenth and eighteenth centuries. ${ }^{27}$

Aware of the emerging role of the Plaza del Mercado as a center for trade and public events, the city council of Baeza agreed to build a new alhóndiga or granary in its perimeter. This building, which connected to the existing municipal pósito and its storerooms, provided additional space to the city for the selling and store of comestible goods. ${ }^{28}$ Its ideal location in the market center also allowed the municipal officials to keep an eye on the trading activities, making sure everything was according to the existing legislation in terms of food supply [Fig. 7].

25. After a fire destroyed the interior of the Casa de Miradores on December 31, 1879, the building was completely demolished. A print published in the periodical La Ilustración Española y America (No. II, January 15, 1880, p. 28) illustrates this tragic event. See also RAFAel López Guzmán: Tradición y clasicismo en la Granada del siglo XVI: Arquitectura civil y Urbanismo, Diputación Provincial, Granada, 1987, pp. 519-524; Rafael López Guzmán: «Miradores y logias municipales», PH Boletín del Instituto Andaluz del Patrimonio Histórico, 57, 2006, p. 48.

26. José Policarpo Cruz Cabrera: Patrimonio arquitectónico y urbano en Baeza (siglos XVI-XVII): aristocracia urbana y conmemoración pública, Universidad de Granada, Granada, 1999, p. 170.

27. Perhaps one of the most singular examples of this transformation, clearly traced and documented by historian Jesús Escobar, can be found in the Plaza del Arrabal of Madrid, future Plaza Mayor (Jesús Escobar: The Plaza Mayor and the Shaping of Baroque Madrid, Cambridge University Press, Cambridge, 2009 [first published: 2004]).

28. Archivo de la Real Chancillería de Granada. Legajo 3-697-1, 1555, in Cruz Cabrera, Patrimonio arquitectónico, p. 192. There are reports about works in the municipal granary since 1544 . 


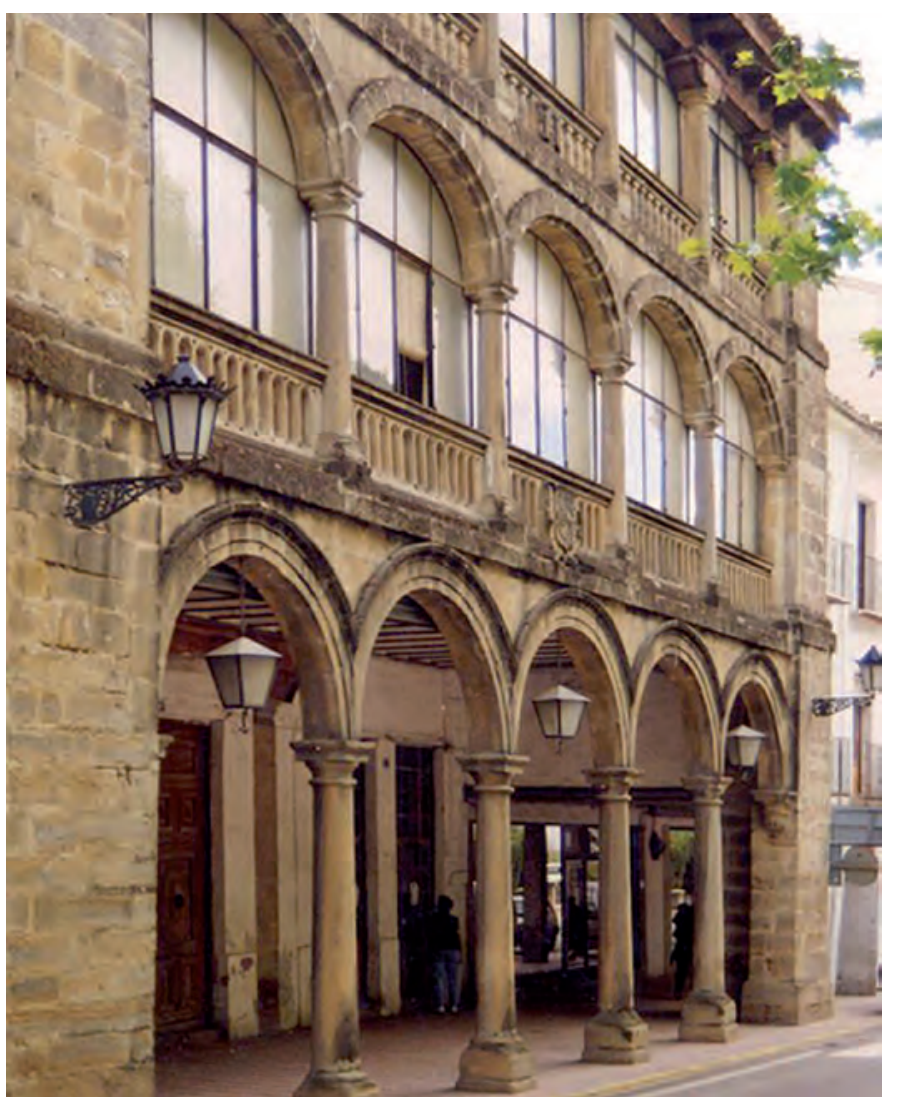

Fig. 7. Municipal Granary, Baeza. Source: http://audioguia.baeza.net/indexes. html?google=es\#detalles_20_199 [access: June 1, 2012]

Although these functions were common to other contemporary Castilian granaries, what was original in the Alhóndiga of Baeza was the design of its front in the Plaza del Mercado. Traditionally, these public buildings were conceived as solid constructions with closed façades, according to their function of grain storage. This design, however, was replaced in the case of Baeza by an open façade, completely diaphanous, consisting of lower porticoes and top corridors, both of them arched and supported by Tuscan columns. This front not only facilitated the market activities, providing inhabitants of Baeza and traders a covered portico; but also ensured the presence of the local authorities in this new urban stage. Francisco de Torres described the Alhóndiga as a big house, «in which [lower] porticoes the kneaded bread and the grain are sold, all the dried fruits, [and] where the Public Weighing House is; it is very ample, with windows in the corridors [made out] of hewn stone, its place [is] in the [Plaza del] Mercado». ${ }^{29}$

29. Francisco de Torres: Historia de Baeza del P. Francisco de Torres S. J. (1677), Ayuntamiento, Baeza, 1999, p. 100. 
In 1590, the aldermen started to debate about building a new arcade or municipal balcony in one of the entrances to the Plaza del Mercado. Given the increasing use of this square, at the end of the sixteenth century the single corridor of the granary seemed to be insufficient to accommodate the town government and the elite of Baeza. Moreover, a more prominent location in the perimeter of the square could be chosen for the new balcony, emphasizing even more the distinction of the city rulers. However, the construction did not start at that time and the granary remained as the only public building in the square until the late seveenth-century and, therefore, the most appropiate mirador for the municipal dignitaries. ${ }^{30}$

This type of façade was also used, with similar purposes, in sixteenthcentury granaries and public buildings erected in the main squares of other Castilian cities. In Córdoba, for instance, the urban planning promoted by the city council in the open space of Corredera prompted the construction of a number of public buildings since the mid-sixteenth century, such as the new granary, the municipal prison and the corregidor's dwelling. The frequent use of this urban space for celebrations and ceremonies helped to increase the importance of the Plaza de la Corredera and certainly influenced the design of the municipal infrastructures erected there, particularly the granary. In fact, the inside of this building followed the traditional layout of solid and rectangleshaped rooms used for grain storage; however, in the front, the two-story granary consisted of arcades which provided the needed municipal balconies for a square with plenty of events in the late sixteenth-century.

Upon the arrival of King Philip II in 1570 and encouraged by the diligent corregidor Francisco Zapata de Cisneros, the city council of Córdoba increased notably the adornment of the Plaza de la Corredera and, consequently, the number of festivals occurring in this space. ${ }^{31}$ Until the nearby House of Corregidores and jail was planned by architect Juan Ochoa and completed in 1586, the galleries and windows of the granary were the only space that could serve as a distinguished balcony for the municipal authorities. ${ }^{32}$ In fact, given the growing amount of activities and participants, in 1575 some members of the city council and the corregidor were appointed to correctly «distribute the windows of the granary, and spaces in the lower-floor, in the Plaza de la Corredera [for the city officials and other authorities]». ${ }^{33}$ Among other events,

30. Currently, the granary has a third floor, also conceived as an open gallery, which was added in 1965. See José Molina Hipólito: Baeza histórica y monumental, Monte de Piedad y Caja de Ahorros de Córdoba, Córdoba, 1982, p. 15.

31. On this adornment of the city and the square, which also included the construction of a splendid jasper fountain, see Pedro de Madrazo: Recuerdos y Bellezas de España. Córdoba, Repullés, Madrid, 1855, pp. 312-314.

32. Marías Yllescas Ortíz: «Evolución urbanística de la Plaza de la Corredera», Axerquía, 5, 1982, pp. 159-175.

33. Archivo Municipal de Córdoba, Sección V, serie 8, No. 8; Actas Capitulares, caja 41, July 20, 1575, in María Dolores Puchol Caballero: Urbanismo del Renacimiento en la ciudad de Córdoba, Diputación Provincial, Córdoba, 1992, p. 109. 
on November 15, 1580, the city organized several festivities in this square as a thanksgiving for the recovery of King Philip II from a serious illness and also for the incorporation of the kingdom of Portugal into the Crown of Castile. These celebrations, witnessed by the municipal government from the corridors of the granary, consisted of a bullfight with fourteen bulls and several juegos de cañas or jousting games, "with six teams of knights, of ten knights each, all wearing six different colors, with costumes of woolen cloth with thread trimming, [and] without having silk except in the sleeves and wearing hoods as they wanted». ${ }^{34}$

A similar façade design of arcades was also used for the sixteenth-century granaries of Priego de Córdoba and Ávila. The construction of the granary in Priego, which has traditionally been atributted to architect Francisco del Castillo, started in 1572 and for its location the aldermen chose the Plaza del Palenque. In addition to its use as the town's market, this square was also becoming a new and important urban space, where the city council did not have any distinguished public building. Thus, for the front of the granary the city approved a design of «upper and lower corridors with all the marble needed from the quarry of Jorque Questa, place of Bernave, because they are very fine and of much benefit». ${ }^{35}$ This large façade was, no doubt, an excellent mirador for the Priego's town government to perform its power. In order to emphasize this visual message, the municipal authorities also made use of the customary sculptural ornamentation carved in the public buildings. The regal and municipal arms, and occasionally also the corregidor's heraldry, were incorportated in a prominent location on these granaries, considering their transformation into eventual balconies [Fig. 8 y 9 ]. ${ }^{36}$

34. Rafael Ramírez de Arellano: Juan Rufo. Jurado de Córdoba. Estudio biográfico y crítico, Hijos de Reus, Madrid, 1912, p. 48. In 1683, the sixteenth-century façade of the granary disappeared, following the extensive and more uniform shaping of the Plaza de la Corredera (Alberto Villar Movellán: «Esquemas urbanos de la Córdoba renacentista», Laboratorio de Arte, 11, 1998, pp. 112-115; Pósitos, cillas y tercias de Andalucía: catálogo de antiguas edificaciones para almacenamiento de granos, Junta de Andalucía, Sevilla, 1991, pp. 218-219).

35. Archivo Municipal de Priego, Leg. 3. Actas Capitulares, February 6, 1572, in Arsenio Moreno Mendoza: Francisco del Castillo y la arquitectura manierista andaluza, Asociación «Pablo de Olavide», Jaén, 1984, p. 165. As described by historian Madoz before it was torn down in the twentieth century, this building «has two galleries, the lower one has seven arches supported by pilasters, and the upper [one] thirteen over columns» (Pascual Madoz: Diccionario Geográfico-Estadístico-Histórico de España y sus posesiones de Ultramar, Pascual Madoz, Madrid, 1849, vol. XIII, p. 218).

36. In Ávila, although the city presumably had an older granary at least since 1520, a new building was erected in the time of King Philip II in the mentioned Plaza del Mercado Grande. This space was located just outside the Medieval walls of Ávila, before entering the city through the Puerta del Alcázar. In the sixteenth century, given the expansion of the city, it became an important trade center and also a frequent location for festivals As was reproduced in the nineteenth century before being demolished, the municipal granary was a solid construction. According to the customary design of Castilian granaries, its façade was closed, provided with just a few openings, and adorned with carved arms. However, one of the corners of this building, on its upper floor, was conceived as an open corridor with lintels supported by columns. This gallery, given the absence of any other public building in that space, was presumably used as a balcony for the municipal authorities to witness the events happening in the Plaza del Mercado Grande and in front of the referred city gate, one of the main entrances into the Medieval Ávila (See JuAn Martín CARRAMOLINO, Historia de Ávila, su provincia y obispado, Librería Española, Madrid, 1873, vol. III, p. 122; José MARía 


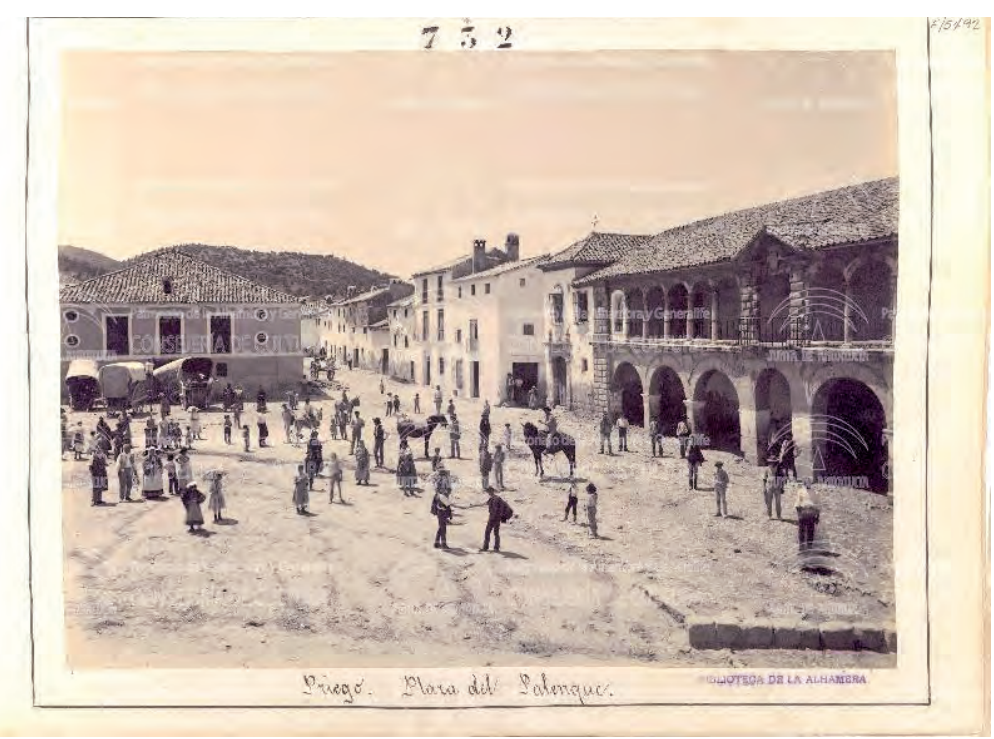

Fig. 8. «Priego. Plaza del Palenque» [and view of the granary], José García Ayola, [1863-1900], APAG/ Colección de Fotografías/ F-05492, Granada, Archivo del Patronato de la Alhambra de Granada. Source: http://hdl.handle.net/10514/12949

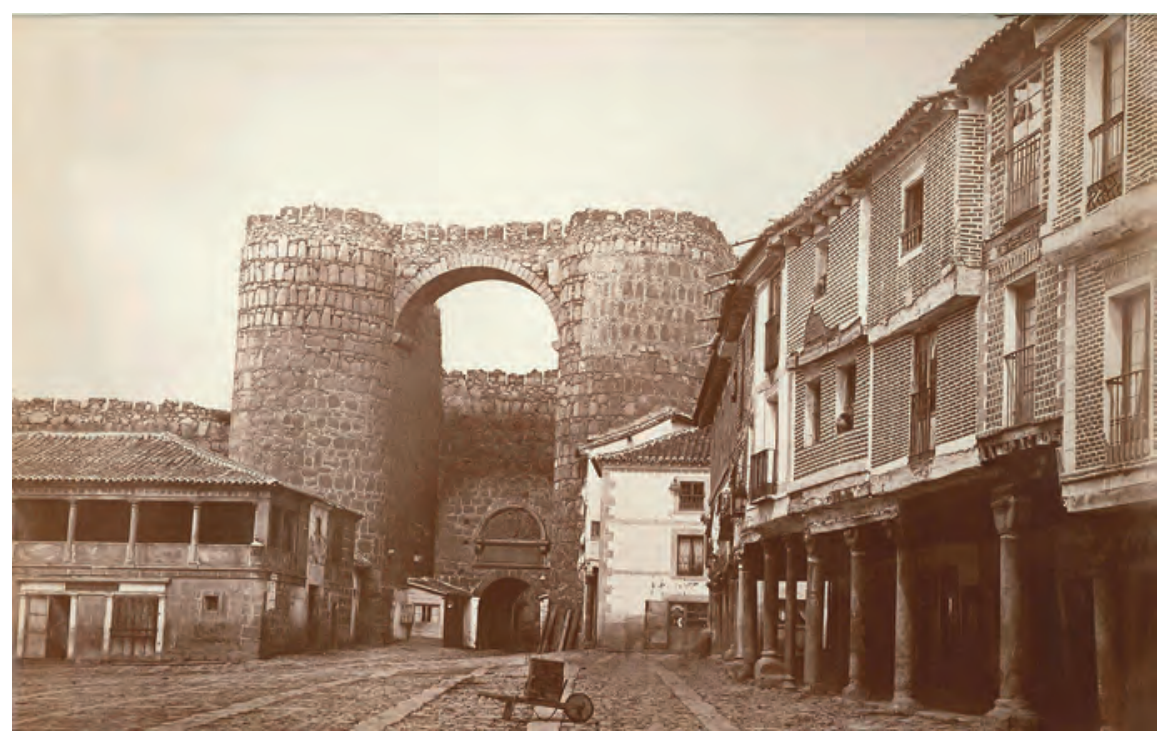

Fig. 9. Puerta del Alcázar and Municipal Granary, Ávila, Charles Clifford, Circa 1860, Colección José Luis Pajares. Source: http://www.flickr.com/photos/avilas [access: June 1, 2012]

QuAdrado, España. Sus monumentos y artes. Su naturaleza e historia. Castilla la Nueva. Guadalajara y Cuenca, Daniel Cortezo, Barcelona, 1884, p. 447; José Belmonte Díaz, La ciudad de Ávila. Estudio histórico, Caja de Ahorros de Ávila, Ávila, 1986, p. 260; José Miguel MuÑoz JiménEz, «El urbanismo del siglo de oro en Ávila: la modernización de la ciudad medieval (1550-1650)», Butlletí de la Reial Acadèmia Catalana de Belles Arts de Sant Jordi, XII, 1998, p. 150). 
Granaries were not the only public buildings used as municipal miradores when the city council lacked an appropiate or exclusive house for this important role. In Burgos, as mentioned above, the adjacent squares of Mercado Mayor and Mercado Menor were becoming the city's center and their perimeters were used for the most significant celebrations. In fact, these public spaces were used to commemorate the arrival to the city of Queen Anna of Austria in 1570, while first traveling from her Central European country to meet her husband-to-be, King Philip II, and the Spanish Court in Segovia. The royal visit was widely celebrated and the squares of Mercado Mayor, and Mercado Menor turned into an splendid urban stage, magnificently adorned for such a solemn event by the ecclesiastical and political authorities of Burgos. ${ }^{37}$

By the second half of the sixteenth century, as mentioned, the city council was already using its new hall inside the reformed Gate of Santa María. However, the aldermen did not have an appropiate and distinguished balcony to view parades and festivals in the same way as other contemporary Castilian cities. In order to resolve this situation, the municipal dignitaries of Burgos finally agreed in 1583 to commission architect Lope García de Arredondo to reform the city gate or Puerta de las Carretas, which was the access point used by merchants entering the Plaza del Mercado Menor. The remodeling work, completed in 1587, consisted of building some galleries on the front of this existing gate, which provided additional space for the town government to see the festivals occurring in the plaza, as the documents read. ${ }^{38}$ Just a few years after completion of this municipal balcony, the city of Burgos was getting ready to celebrate another royal visit. In 1592, King Philip II arrived to the city on his way to the territories of Aragon. This time, although the celebrations were moderate given the non festive character of the monarch, the Plaza del Mercado Menor also housed several activities for whose viewing the city council already had a permanent space. ${ }^{39}$

37. Multiple and rich tapestries were used in the Plaza del Mercado Menor to decorate the façades of its buildings, which were so crowded that there was no more room for the people «either in windows, roofs, or stages» arranged in the square (Relacion muy verdadera del alto recibimiento, que la ciudad de Burgos hizo a la Serenissima y muy poderosa señora la Reyna doña Anna ... in MARía Jesús SANz LuCAS: «Festivas demostraciones de Nimega y Burgos en honor de la Reina Doña Ana de Austria», Boletín del Semanario de Estudios de Arte y Arqueología, 49, 1983, p. 394).

38. Archivo Municipal de Burgos, Histórica, 5283. Year 1583, in IBÁñez Pérez, Arquitectura civil, p. 321. See also Matías Martínez Burgos: Puente, Torre y Arco de Santa María, Ayuntamiento de Burgos, Burgos, 1952.

39. Despite the reform completed by architect Arredondo, the Puerta de las Carretas was presumably a very modest and simple construction. In fact, according to historian López Mata, during the bullfight celebrated in the Plaza del Mercado Menor to commemorate his visit, King Philip II was not accommodated in these galleries, but in the houses of a distinguished inhabitant of Burgos, Diego de Osorio, whose dwelling had already been used two decades earlier by the Queen Anna of Austria to witness the festivals organized for her in the same square (TEÓfIlo López MATA: «Burgos durante la estancia de Felipe II en 1592», Boletín de la Comisión Provincial de Monumentos Históricos y Artísticos de Burgos, 53, 1935, pp. 291-303). Following the increasing significance of this square, in the eighteenth century the aldermen of Burgos decided to move for good from their former location in the Gate of Santa María. They settled down permanently in the Plaza del Mercado Menor where a large and Neoclassical city hall was newly erected on the site formerly occupied by the Puerta de las Carretas (See Rodrigo AmAdor DE LOS Ríos: España, sus monumentos y artes, su 
More controversial was the reaction of the municipal government in León regarding the location of the city hall, away from what was the main public square in the late sixteenth and early seveenteenth centuries. Following their efforts to minimize the importance of the Plaza de Regla and the ecclesiastical power, the aldermen still lamented in 1603 the illogical situation of León given that «in all the cities in Spain the festivals are celebrated where the city halls are». ${ }^{40}$ A new and solid city hall was completed in 1586 after the plans of mentioned Juan del Ribero Rada; however, the council seemed to fight a losing battle against the ecclesiastical authorities and their defense of the Plaza de Regla as urban center of León. Consequently, in the early seventeenth-century the aldermen agreed to augment their visual presence and authority in this latter square by remodeling the existing city's balcony into a larger and more decent structure. This time the proposal of the town government seemed more ambitious in its last attempt but one to seize the leading urban role from the religious power. In addition to purchasing a building adjacent to their existing mirador, the aldermen debated to also reform this last construction and transform it into a new city hall. Thus, they could move from their location in the Plaza de San Marcelo and occupy a larger and more «modern» building in the Plaza de Regla. In their minds still persisted the old eagerness for their public architecture to visually demonstrate their power and prevalence in the urban space. However, the magnificent «Paredón de Regla», the Renaissance construction erected for the cathedral chapter a few years earlier, still stood as a powerful architectural emblem in the latter square. ${ }^{41}$

This visual display of authority reached its peak in the following two centuries when the chief public squares transformed into more crowded and spectacular stages in accordance with the development of the Baroque culture. The Plaza Mayor emerged as a more regular and uniform space, able to «receive -as Father Francisco de Torres affirmed referring to the Plaza del Mercado in Baeza- countless people on the occasion of bullfights and other public events» ${ }^{42}$ In this context, the balconies and casas de miradores, although originated in the sixteenth century, remained as a booming phenomenon throughout the Early Modern Era. Given its functionality and symbolism, this public architecture of municipal balconies widely spread to other Castilian cities since the early seventeenth century.

naturaleza e historia. Burgos, Daniel Cortezo, Barcelona, 1888, pp. 676-681; RENÉ-Jesús PAyo HeRnAN and Ana Berta Nieto Plaza: «Ornato y amueblamiento de las nuevas Casas Consistoriales de Burgos (17831790)», Boletín de la Institución Fernán González, 216, 1998/1, pp. 69-101).

40. Archivo Histórico Municipal de León, Libro de Acuerdos, 20, caja 45, August 13, 1603, in CAMpos SÁnchez-Bordona and Pereiras Fernández, Iglesia y ciudad, p. 382.

41. Campos Sánchez-Bordona and Pereiras Fernández, Iglesia y ciudad, pp. 326-346. Despite the pretentious proposals of the aldermen, the hall for their meetings was never moved and the existing balcony of the city maintained its place and functions in the Plaza de Regla for decades. The opening of a new Plaza Mayor in León during the second half of the seventeenth century partly achieved the long-awaited goals of the city council. A large and adorned balcón de la ciudad, erected in a central location in the new square, allowed the aldermen to solemnly preside over the festivals without any other powerful competitors.

42. Torres, Historia de Baeza, p. 101. 
In Sigüenza, for instance, two different squares were mostly used during the sixteenth century. The original Plaza Mayor, located in the upper side of the Medieval town housed along its perimeter a city hall erected in the late fifteenth century and completed with new additions during the sixteenth century. On the opposite side of town, in an open space near the cathedral, the Cardinal Mendoza ordered a new public square to be created in the late fifteenth century. In the following decades, this latter square or Plaza Nueva was gradually shaped and became the most notable urban space and the market center of Sigüenza. By the early seventeenth century, the city council had become resigned to this urban scene. Despite the aldermen's continuous complaints, the ecclesiastical authorities, ultimately the lords of Sigüenza, gave priority to the new square over the Plaza Mayor. Consequently, in 1613 the city council agreed to purchase some old houses in the new square, formerly owned by the cathedral chapter, and transform them into a casa del mirador. Certain disagreements between the city council and the cathedral chapter postponed the works, finally initiated in 1652. The resulting building was located to the «east of the Plaza Pública, south of the Chapter House, north of the Holy Church's Treasury, and west of the Romeros Chaplaincy». As for its façade, it had «three floors, serving one for the city council's events and mirador of the city in the bullfights; and the other two have six balconies rented to private residents for the said festivals» [Fig. 10 y 11$].{ }^{43}$

43. Archivo Municipal de Sigüenza. Actas, Libro VI; Archivo Catedralicio de Sigüenza. Actas Capitulares, Libro 19, tomo 47, ff. 82v, 83r, July 31, 1613; Archivo Catedralicio de Sigüenza, Actas Capitulares, Libro 23, tomo 59, f. 121; Archivo Municipal de Sigüenza. Actas, Libro IX, February 12, May 25, September 30, 1652; Archivo Municipal de Sigüenza. Libro de Haciendas de Legos, f. 179, 1753, in Pedro Ortego GiL: «Notas para la historia de los edificios seguntinos (I)», Anales Seguntinos, 3, 1986, pp. 143-146. In the city of Viana, following financial prosperity and the desire to improve the public architecture, a more splendid municipal balcony was also erected in the second half of the seventeenth century in the Plaza del Coso. Although the aldermen met in the Plaza Mayor, where a new city hall was also built at that time, the Plaza del Coso was the urban space traditionally used for the celebration of bullfights. The sixteenth-century wooden structures or «tablados» used for the municipal authorities on the occasion of these festivities were replaced by a large new building, the Balcón de Toros, whose façade followed the customary architecture of arcades for balconies and casas de miradores (see JuAn CRUz LABEAgA MENDiola: «La Casa Consistorial y los balcones de toros de la ciudad de Viana (Navarra)», Príncipe de Viana, 154-155, 1979, pp. 101-176; ConCEPCIÓN García Gaínza: Catálogo monumental de Navarra. II. Merindad de Estella. Genevilla-Zúñiga, Institución Príncipe de Viana, Pamplona, 1983, vol. II, p. 618). In Antequera, a house with «miradores for festivities» was also erected in 1672 by the architect Fray Pedro del Espíritu Santo. This building, constituted of lower porticoes and upper corridors, was located in the Plaza de San Francisco. Throughout the seventeenth century, this open space, together with the Plaza de San Sebastián, gradually replaced the Plaza Alta, traditional seat of the municipal authorities and where the city hall was situated, as main square and center of public celebrations and festivals (Antonio PARejo Barranco: Historia de Antequera, [Caja de Ahorros de Antequera], Antequera, 1987, pp. 88-92). 


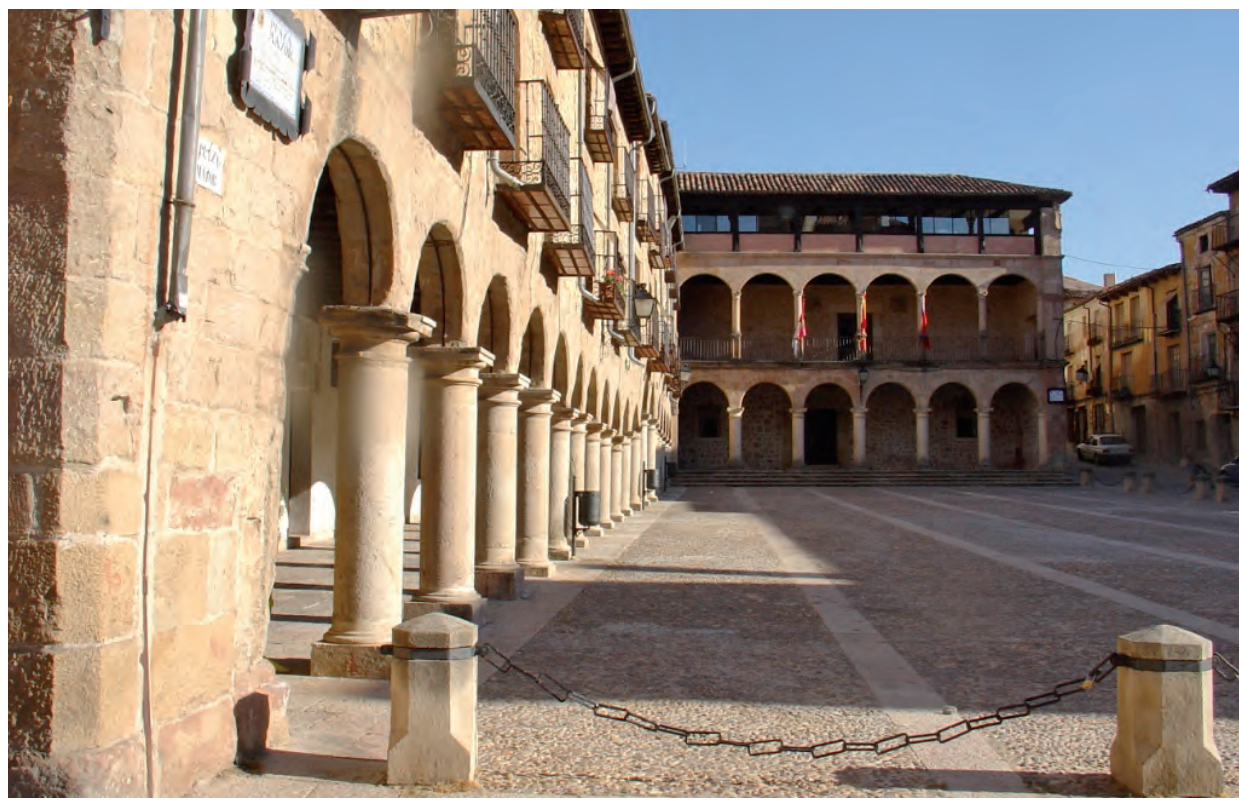

Fig. 10. Plaza Nueva and Casa de Miradores, Sigüenza. Source: http://descubriendogadalajara. blogspot.com/2011_12_01_archive.html [access: June 1, 2012]

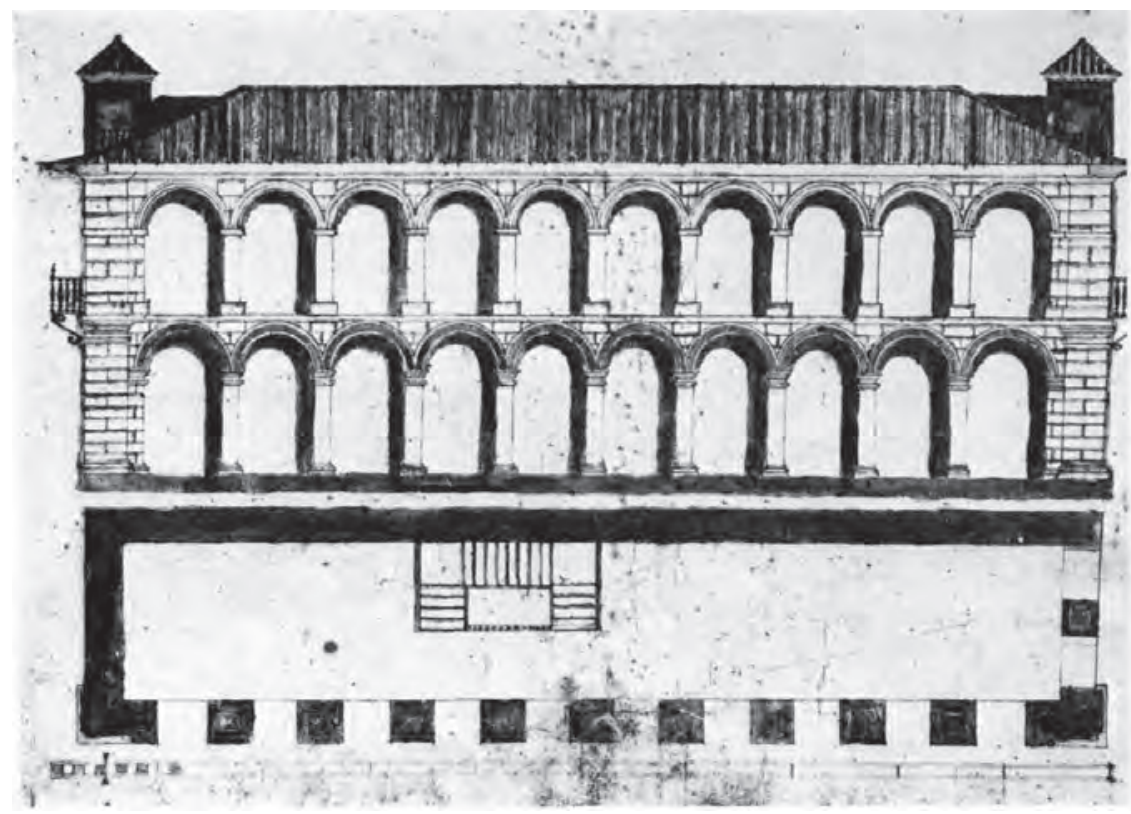

Fig. 11. Elevation of the Balcón de Toros, Viana, Juan de Raón, Archivo Municipal de Viana, Navarra. Published in: Juan Cruz Labeaga Mendiola, «La Casa Consistorial y los balcones de toros de la ciudad de Viana (Navarra)», Príncipe de Viana, 154-155, 1979, image No. 8 


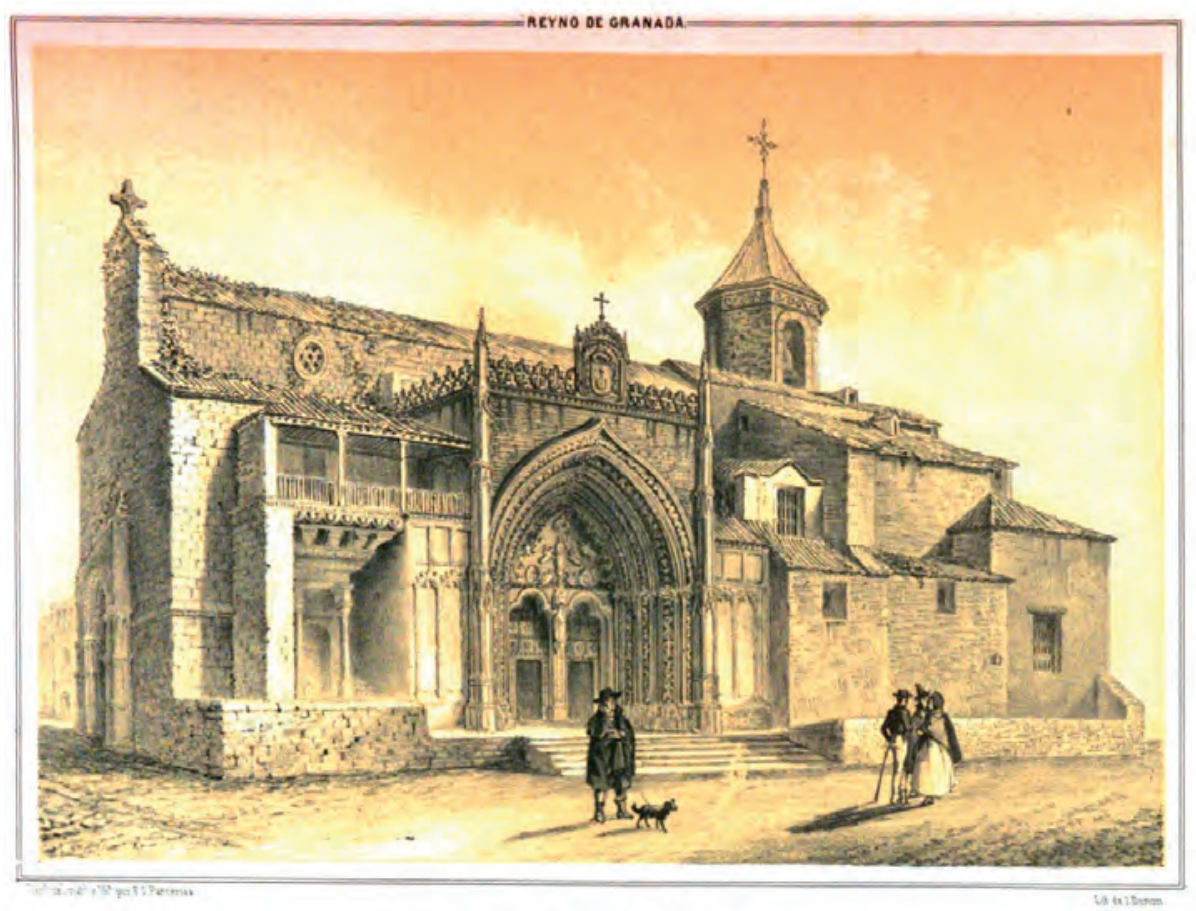

IGLESIA DE Sn PABLO EN UBEDA.

Fig. 12. Iglesia de San Pablo en Úbeda and the «Tabladillo», Francisco Javier Parcerisa (drawing),1850. Published in: Pedro de Madrazo, Recuerdos y Bellezas de España. Reino de Granada, Imprenta de Repullés, Madrid, 1850 [image between pp. 212 and 213]

In the early seventeenth century, the construction of large and solid balconies for some town governments was also a slow process that did not culminate until decades later. In the meantime, as it happened in Úbeda, the city councils made use of modest wooden structures, occasionally attached to the religious buildings standing in the plazas. With this purpose, in the early seventeenth century, the municipal goverment of Úbeda used the so-called «tabladillo», a wooden balcony located in the front of San Pablo's Church, which temporarily provided a mirador for the aldermen in the main urban square, the Plaza del Mercado [Fig. 12]. ${ }^{44}$

Not far away from this religious building, the city council already had a solid city hall. It had been erected in the early sixteenth century and remodeled a few decades later, presumably under the direction of architect Andrés de Vandelvira. The two fronts of this building were facing the Plaza del Mercado and the Plaza de Abajo, open public spaces that by then were adjacent and

44. This balcony still existed in the nineteenth century when Parcerisa reproduced it in a printed image of San Pablo's Church (Pedro de Madrazo: Recuerdos y Bellezas de España. Reino de Granada, Repullés, Madrid, 1850, pp. 212-213). 
had received different names. However, in the early seventeenth-century the existing city hall of Úbeda did not have galleries facing these squares. In fact, its façade consisted of a number of window openings until 1609 when the city agreed to add some porticoes and corridors to the sixteenth-century architectural fabric. As historian Arsenio Moreno Mendoza has pointed out, certain problems in the foundation and elevation of these first arcades presumably encouraged the city council to replace the top gallery, used as a municipal balcony or mirador over the Plaza del Mercado. The new one was completed in 1680, as states the commemorative inscription carved in the entablature of this corridor and still preserved..$^{45}$

A similar situation was experienced in the city of Guadix in the early seventeenth century regarding this issue of municipal balconies over the chief public square. Following its reconquest by the Catholic Monarchs in the late fifteenth century, an open esplanade outside of the city walls started to be used as the market center. Around 1500, the aldermen also occupied this space using an existing construction as a hall for their meetings. This modest construction was gradually remodeled and adorned in the sixteenth century. In addition to the hall for the aldermen, its interior also housed the quarters for the corregidores or royal magistrates in town, and the façade, erected with lower porticoes and upper-floor balconies, offered, as in other Castilian cities at that time, an appropiate balcony for the political authorities. ${ }^{46}$ By the early seventeenth century, however, this building seemed to be insufficient for accommodating both the king's representative and the aldermen. Considering the increasing importance of the Plaza Mayor, the city council agreed then to erect a new building in front of their existing hall, in which the corregidores would be more decently housed. This new construction was projected as an additional mirador or balcony for the authorities and elite of the city; and consequently, its façade was also designed according to what was traditional in this type of public architecture since the sixteenth century. In fact, the large façade of lower and upper arcades over columns and the architectural crowning of small niches with carved heraldry was, in a certain way, reminiscent of the design used by architect Siloé decades before in the Casa de los Miradores of Granada [Fig. 13]. ${ }^{47}$

45. At the end of the eighteenth century, the building was altered one more time. The porticoes and corridors facing the Plaza de Abajo were removed, remaining only the arcades looking towards the Plaza del Mercado (Arsenio Moreno Mendoza: Urbanismo en la Úbeda del siglo XVI: entre la tradición medieval y la reforma, Instituto de Estudios Giennenses, Jaén, 2005, pp. 115-118).

46. Archivo Histórico Municipal de Guadix, leg. 5, ff. 31, 37, in Carlos Asenjo Sedano: Arquitectura religiosa y civil de la ciudad de Guadix. Siglo XVI, Universidad, Granada, 2000, pp. 210, 212.

47. The construction was directed by architect Juan Caderas de Riaño and concluded in 1606, according to the inscription carved in the frieze crowning the façade: «LA CIUDAD MANDÓ HACER ESTA OBRA SIENDO CORREGIDOR DON ANTONIO ÁlVAREZ DE BOHÓRQUEZ CABALLERO DEL HÁBITO DE SANTIAGO JENTIL HOMBRE DE LA CASA REAL DE SU MAGESTAD DON FELIPE III ALGUACIL MAYOR DEL SANTO OFICIO DE LA YNQUISICIÓN DE LA CIUDAD Y REINO DE GRANADA VEINTICUATRO DE LA CIUDAD DE CÓRDOBA. EL DOCTOR DON FRANCISCO DE VILLALTA DÁVALOS SU ALCALDE MAYOR. AÑO DE 1606 (See Archivo Histórico Municipal de Guadix, Legajos 1-5; Archivo de Protocolos Notariales de Guadix. Protocolo de Antonio de 


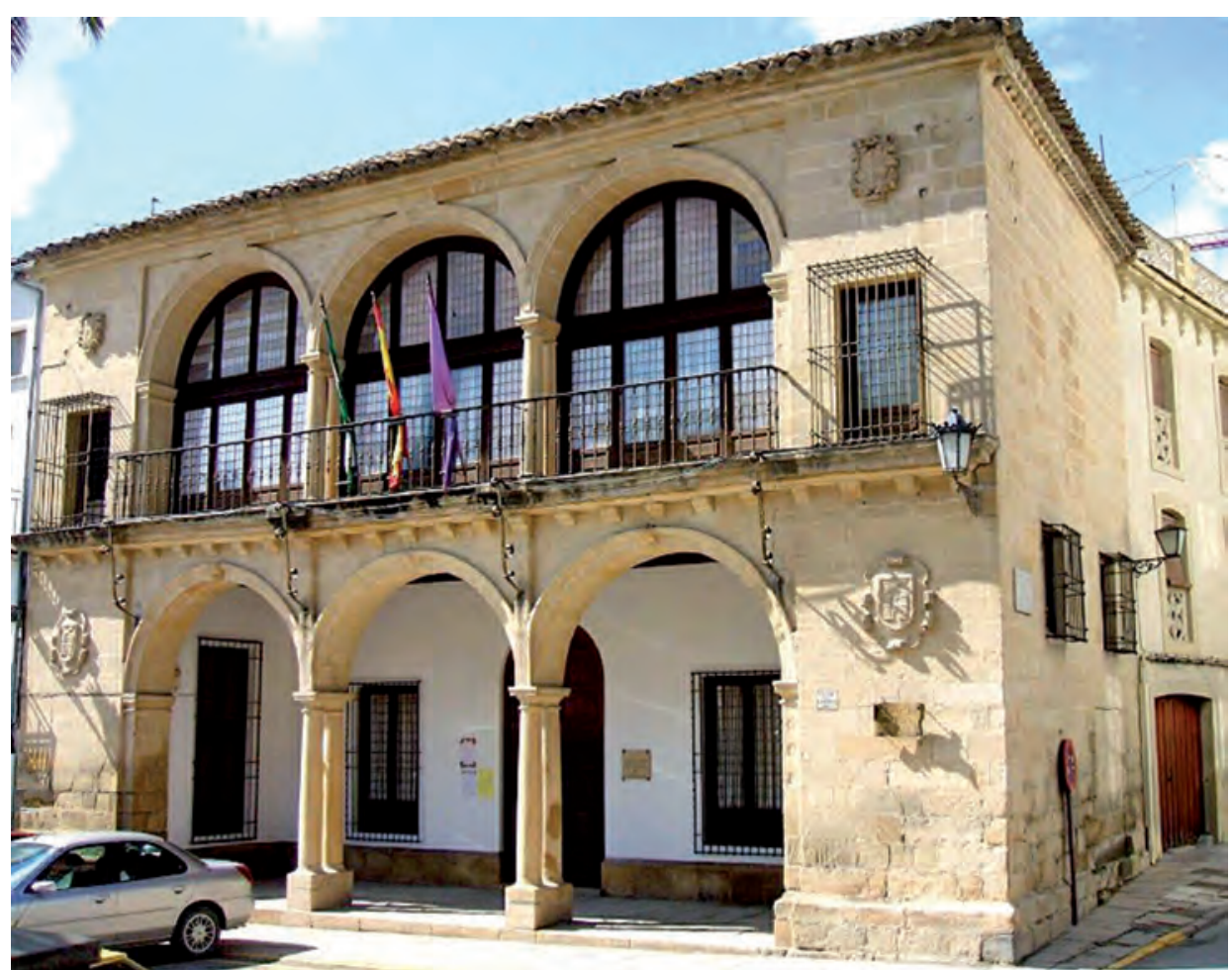

Fig. 13. Façade of Balcón de Corregidores, Guadix. Detail, Circa 1930. Source: http:// accitanosdelaestacion.es $/$ index.php? module $=$ mediashare $\&$ func $=$ browse $\&$ aid $=138 \&$ mid $=1242$ [access: June 1, 2012]

This need to increase their presence and emphasize their power in the public space encouraged the city councils to even defray the construction of additional casas de miradores in squares where they already had similar public architecture. For instance, in Badajoz, some «important [and] painted houses where this city has its balcony for the festivities» were used since the midsixteenth century. ${ }^{48}$ These houses were located in the Plaza Alta or chief public square in the city, «which serves as market, [and] where the Ayuntamiento [city hall] and its Clock is». ${ }^{49}$ However, as happened with the municipal balcony in León, they did not occupy a central and more distinguished position in that urban space. Although the aldermen acknowledged this problem and started debating it in the early seventeenth century, no works were initated until

Hinojosa, December 20, 1604, in AsENJo SEDANo, Arquitectura religiosa y civil, pp. 212-213 y 215. After the fire destroyed most of the Plaza Mayor in 1936, the Balcón de los Corregidores was reconstructed following the original design, but erected on the opposite side of the square, formerly occuppied by the city hall (see LóPEZ GuZMÁN, «Miradores y logias municipales», p. 48).

48. Archivo Catedralicio de Badajoz, legajo 378, expediente 5161, October 5, 1558, in José MANUeL González González: La Plaza Alta de Badajoz. Estudio Histórico-Artístico, Junta de Extremadura, Badajoz, 2006, p. 82.

49. Jouvin, El viaje de España y Portugal, vol. II, pp. 799-800. 


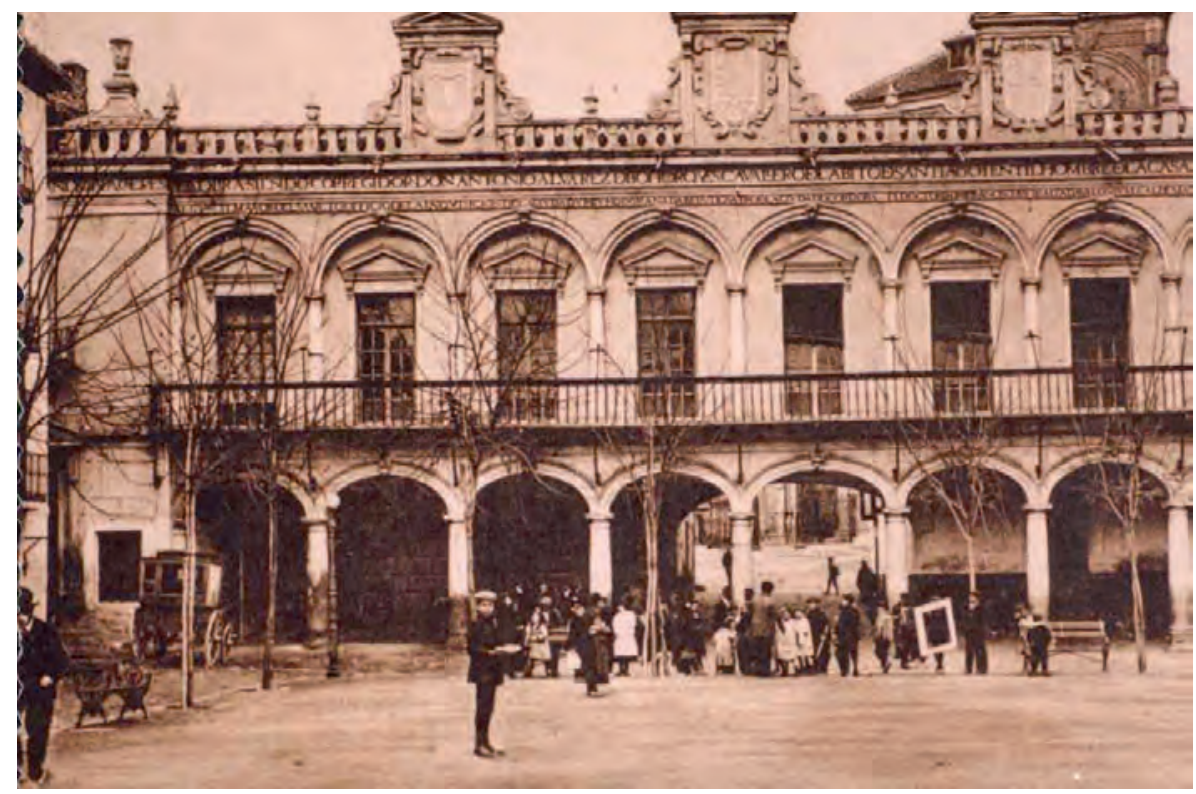

Fig. 14. Balcony of the City, Baeza. Source: http://commons.wikimedia.org/wiki/File:Baeza_-_ Balcon_del_Concejo.jpg [access: June 1, 2012]

decades later and the additional «arch and balcony for the city to be present in the festivals» was completed in $1695 .^{50}$

In Baeza, as mentioned above, since the mid-sixteenth century the city council had been using the new granary as their balcony to witness the celebrations in the Plaza del Mercado. In the seventeenth century this plaza became one of the finest and largest public spaces in Southern Spain, a «Plaza Mayor» in the words of Francisco de Torres, comparable with the Plaza de Bibarrambla in Granada and the Plaza de San Francisco in Sevilla. Aware of the increasing number of activities happening in that space, and despite the existing galleries of the granary, the city council of Baeza finally agreed to build a new municipal balcony, completed by the late seventeenth-century, which would be exclusively dedicated to visually perform their power and would offer a more centralized and distinguished location for the aldermen within the limits of the Plaza Mayor. Their status and functions, as rulers of the city, justified a larger and more prominent presence in such a bustling and significant urban space [Fig. 14]..$^{51}$

50. Archivo Municipal de Badajoz, libro de actas No. 23, October 11, 1694, f. 73r, in GonzÁLez GonzÁlez, La Plaza Alta, pp. 84-84, 126-127. Given the location of the cathedral in the lower part of the city, the ecclesiastical authorities of Badajoz did not have their own balcony to witness the celebrations in the Plaza Alta until the seventeenth century.

51. José Molina Hipólito: «El balcón de la ciudad de Baeza», Boletín del Instituto de Estudios Giennenses, 51, 1967, pp. 53-56; Cruz Cabrera, Patrimonio arquitectónico, pp. 73-78; José Policarpo CRUz CABrera: «Arquitectura civil en Baeza a fines del siglo xviI: el balcón de la ciudad (1686-1701)», in Actas del Congreso sobre la Andalucía de finales del siglo XVII, Ayuntamiento, Cabra, 1999, pp. 129-144. 
In these balconies, as happened inside the meeting halls of the city councils, a strict protocol was also observed for the seating assignment of the authorities. In accordance with a hierarchical organization of the municipal power, the corregidor, as delegate of the monarch in the city, occupied the most central and distinguished space. Also in a noticeable location were the aldermen or veinticuatros, with the oldest ones in office seated closer to the corregidor. Beyond them, the seats were distributed, always depending on the available space, among other municipal dignitaries, ecclesiastical authorities and distinguished inhabitants and elite. Francisco Cabeza de Vaca, a local noble of León and member of its municipal government, described in very eloquent terms the arrangement of the authorities in the «Mirador de la Ciudad» on the occasion of bullfights. Although he was referring to the large and Baroque building erected in the new Plaza Mayor during the last quarter of the seventeenth century, his passage perfectly illustrates something common for the whole Early Modern Era: an ordered distribution of the space in the these balconies, appropiate for the social stratification of that period, and an adorned architecture of open galleries and corridors, essential for that visual performance of municipal power. He wrote:

The house of the City [or Mirador] from where these festivals are witnessed is all [made out] of hewn stone finely carved, and on the edges [of its façade there are] two towers with their arms, [and] slate spires crowning them; and the house, with open corridors in the same stone, and here and there its statues with arms. Crowning the façade and main balcony [there is] a very large [coat] of the Royal [arms], and this beautiful building is a hundred and fourteen feet long, and along it extends a balcony, except in the towers which, for more beauty, have it [their own one] apart. The one that goes with the window in the center, over the entrance, is more projected, somewhat more than the others. In this one, on a day of bulls, the Lord Corregidor stays with all the oldest Caballeros [or aldermen] that fit on it, and the rest [of city officials] follow [behind] to the end of that side. The other one serves for the wives of the city officials, having the gallery divided on that side [...] by an antipara [a type of partition or folding screen], for more decency. There are other continuous balconies under these ones, on both sides of the entrance, that are part of the house's mezzanine. These [balconies] are distributed among the Lord Corregidor and the Aldermen, upon their seniority, [they] are for their guests and families. All the place is hung [adorned with tapestries hanging] with authority and splendor. ${ }^{52}$

52. Francisco Cabeza de Vaca, Quiñones y Guzmán: Resvmen de las politicas ceremonias, con que se govierna la Noble, Leal, y Antigva Civdad de León, Cabeza de sv Reyno, Imprenta de Valdivielso, Valladolid, 1693, pp. 30-31. 